This article was downloaded by: [Memorial University of Newfoundland] On: 28 January 2015, At: 04: 15

Publisher: Routledge

Informa Ltd Registered in England and Wales Registered Number: 1072954

Registered office: Mortimer House, 37-41 Mortimer Street, London W1T 3J H, UK

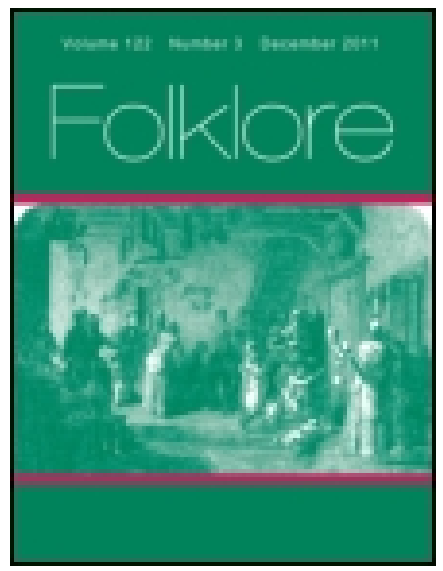

\title{
Folklore
}

Publication details, including instructions for authors and subscription information:

http:// www. tandfonline.com/loi/ rfol20

\section{Dairy Folklore in West Norfolk}

Mr. F. A. Milne

Published online: 14 Feb 2012.

To cite this article: Mr. F. A. Milne (1907) Dairy Folklore in West Norfolk, Folklore, 18:4, 435-436, DOI: 10.1080/0015587X.1907.9719798

To link to this article: http:// dx. doi.org/ 10.1080/ 0015587X.1907.9719798

\section{PLEASE SCROLL DOWN FOR ARTICLE}

Taylor \& Francis makes every effort to ensure the accuracy of all the information (the "Content") contained in the publications on our platform. However, Taylor \& Francis, our agents, and our licensors make no representations or warranties whatsoever as to the accuracy, completeness, or suitability for any purpose of the Content. Any opinions and views expressed in this publication are the opinions and views of the authors, and are not the views of or endorsed by Taylor \& Francis. The accuracy of the Content should not be relied upon and should be independently verified with primary sources of information. Taylor and Francis shall not be liable for any losses, actions, claims, proceedings, demands, costs, expenses, damages, and other liabilities whatsoever or howsoever caused arising directly or indirectly in connection with, in relation to or arising out of the use of the Content.

This article may be used for research, teaching, and private study purposes. Any substantial or systematic reproduction, redistribution, reselling, loan, sub-licensing, systematic supply, or distribution in any form to anyone is 
expressly forbidden. Terms $\&$ Conditions of access and use can be found at http://www.tandfonline.com/page/terms-and-conditions 
with their children and made them kiss it, and the ignorant were in a hurry to get some of its flesh when it was killed on the last day of the Corpus Domini feast. It was supposed to heal diseases.

Lebrun hesitates to see in the above custom a survival of a pagan rite, and cites Ruffi's History of Marseilles to the effect that, according to an Act of the fourteenth century, the confraternity of the most Holy Sacrament had bought an ox to present to the people, and led it through the streets. This must surely be an aetiological story; and it hardly admits of doubt that we have here a trace of an ancient holiday when a bull was first led in procession, and then sacrificed.

F. C. Conybeare.

DAIRY FolkLorg in WeSt Norfolk.

(Communicated by Mr. F. A. Milne.)

[Dr. C. B. Plowright, M.D., of King's Lynn, Medical Officer of Health for the Freebridge Lynn Rural District, reporting to the District Council on his recent inspection of the local dairies, said]: "There had come down from time immemorial various superstitions connected with milk and milking. One of the most widespread of these throughout the whole district was that unless the hands of the milker were washed before and after milking the cow would become dry, or in other words would cease to give milk. Although it could not be said that milk was viewed with exactly superstitious reverence, yet the vessels and utensils used for it were never used for any other purpose. Nor was the milk ever stored in any place where there were any bad smells, as it was believed that the liquid would absorb the aroma. For instance, the milk was never kept near cheese, herrings, onions, or where there was any effluvium from drains. It was also regarded as a universal antidote to all kinds of poisons, and was believed to absorb and convey infectious disease from the atmosphere. 
"It was considered that milk must always be kept quiet, and therefore, the dairy door was never shut violently. To spill it in milking, or, as it was said, 'to milk wide of the pail,' was most scrupulously avoided lest any should fall on the cow's feet and legs, in which case it was the belief the cow would become dry. On the other hand, when a cow was milked the first few drops were used to moisten the palms of the milker, for it was said not to be well to milk with a 'dry hand. Dr. Plowright expressed the opinion that this was a piece of sympathetic magic, and observed with the idea of increasing the quantity of milk obtainable from the animal that was being milked. Again, before the process of milking was regularly begun, one other rite was performed. The teats were 'drawn,' that is, a few drops were milked upon the floor: they were not allowed to fall into the pail, but must be milked upon the ground. The reason assigned for this was that the duct of the teat was by this means washed out, and any dust or impurity that may have got into it, was got rid of before the full milking was entered upon. This, said the medical-officer, was clearly a survival of the rite of sacrifice, a libation poured upon the ground to propitiate the gods with the idea of insuring a plentiful supply. Possibly the sacrifice was made to some Scandinavian deity, such as Freya, or Freyja, or perhaps even to Friga. It was also usual to throw away the last few drops of milk which remained at the bottom of the jug or basin or pail which had contained it. It was alleged by those who had the handling of the milk that any deleterious substance which the milk had absorbed settled to the bottom of the vessel, and by throwing away the last few drops, the impurities were got rid of. It was so general a custom, however, that there could be but little doubt that it was a folk-lore survival, like that of the beggar throwing away the dregs from the cup from which he had taken a drink. However matted a cow's tail might become with filth, the hair must never be cut off with a sharp instrument, as it was believed that this would cause the cow to abort her calf." (Eastern Daily Press, 20th Sept., r907.) 